\title{
A MULHER COMO VÍTIMA FATAL: FEMINICÍDIO
}

\author{
Gabriella Pontes de Lemos Caldeira* \\ Fernando Shimidt de Paula**
}

\section{RESUMO}

Este artigo científico tem por objetivo estudar o conceito de mulher a partir de pesquisas doutrinárias e jurisprudenciais, para aplicabilidade das leis de proteção de gênero, para o que será analisada a Lei do Feminicídio ( $\mathrm{n}^{\circ}$ 13.104/15), o perfil das vítimas e dos criminosos e suas motivações. E, por fim, serão estudadas algumas estatísticas a respeito dessa qualificadora do crime de homicídio.

Palavras-chave: Violência. Mulher. Feminicídio. Gênero.

\section{THE WOMAN AS A FATAL VICTIM: FEMINICIDE}

\section{ABSTRACT}

This scientific article aims to study the concept of women through doctrinal and jurisprudential research, for applicability of gender protection laws, then will be analyzed the Law of Feminicide (no. 13.104/15), the profile of victims and criminals and their motivations And, finally, will be studied and some statistics regarding this qualifier of the crime of homicide.

Keywords: Violence. Woman. Feminicide. Genre.

\section{INTRODUÇÃO}

Desde os primórdios é clara a submissão da mulher ao homem. E com base nisso foi se construindo uma sociedade patriarcal, na qual os homens se utilizam da violência em suas mais diversas formas com o intuito de mostrar que estão no poder e têm domínio sobre as mulheres, colocando-as assim em posição de inferioridade em relação a eles. Esses tipos de comportamento muitas vezes levam os homens a praticar o fator máximo de violência contra a mulher, que é o homicídio em razão do gênero feminino, denominado feminicídio pelo Código Penal Brasileiro, que tipificou o crime como uma das qualificadoras do crime de homicídio por meio da Lei 13.104/15, porém, mesmo após essa tipificação, segundo a Organi-

* Graduada em Direito pela UMESP - Universidade Metodista de São Paulo.

** Mestre em Direito Penal pela Pontifícia Universidade Católica de São Paulo-PUC/SP. Especialista em Gestão do Comportamento pela Universidade Federal de São Paulo - UNIFESP - e em Direito Público pela Escola Paulista da Magistratura - EPM. Professor da Academia de Polícia de São Paulo. Professor da UMESP - Universidade Metodista de São Paulo. Orientador. 
zação Mundial da Saúde (OMS) ${ }^{1}$, o Brasil está em quinto lugar no ranking de países que mais matam mulheres no mundo.

Outrossim, o artigo terá como escopo conceituar o que é mulher para fins de aplicabilidade da Lei Maria da Penha ( $\left.n^{\circ} 11.340 / 2006\right)$ e da Lei do Feminicídio $\left(\mathrm{n}^{\circ} 13.104 / 15\right)$ e apresentar um estudo detalhado do crime de Feminicídio, o perfil das vítimas e dos criminosos e suas motivações e, também, algumas estatísticas a respeito.

\section{CONCEITO DE MULHER}

Atualmente existem três posições doutrinárias para identificar a mulher. A primeira posição diz respeito ao critério biológico, ou seja, refere-se à genética. Sobre esse posicionamento, Mello (2019, p. 143) explica:

[...] o critério biológico, segundo a qual identifica-se a mulher em sua concepção genética ou cromossômica. Neste caso, como a cirurgia de redesignação de gênero altera a estética, mas não a concepção genética, não será possível a aplicação da qualificadora do feminicídio.

Verifica-se que o critério biológico é simples e está relacionado ao sexo em que o indivíduo nasceu naturalmente, ou seja, nasceu geneticamente mulher.

\section{MULHER TRANSEXUAL E A APLICAÇÃO DA LEI MARIA DA PE- NHA (No 11.340/2006) E DA LEI DO FEMINICÍDIO (No 13.104/15)}

Já no que se refere à segunda posição doutrinária, temos o critério psicológico que se aplica às pessoas que entendem não pertencer ao sexo biológico com que nasceram. Essas pessoas são classificadas como transexuais.

França (2005, p. 142) explica o que é transexualismo:

inversão psicossocial, uma aversão ou negação ao sexo de origem, o que leva esses indivíduos a protestarem e insistirem numa forma de cura por meio da cirurgia de reversão genital, assumindo, assim, a identidade do seu desejado gênero. As características clínicas do transexualismo se reforçam com a evidência de uma convicção de pertencer ao sexo oposto, o que lhe faz contestar e valer essa determinação até de forma violenta e desesperada.

A respeito do tema, Mello (2019, p.43) também pontua:

[...] Para essa corrente doutrinária, deve-se desconsiderar o critério biológico para identificar como mulher toda aquela cujos aspectos psíquicos ou comportamentais são femininos. Adotando-se esse critério, matar alguém que fez a cirurgia de redesignação de gênero ou que, mesmo

1 DIÁRIOPB, Brasil está em $5^{\circ}$ lugar em ranking de feminicídios, no mundo aposta OMS. Disponível em: <https://diariopb.com.br/brasil-esta-em-5o-lugar-em-ranking-de-feminicidios-no-mundo-aponta-oms/>. Acesso em: 24/04/2019. 
sem tê-la feito, psicologicamente acredita ser mulher, trará a aplicação da qualificadora do feminicídio.

Cumpre mencionar ainda que "em tese não se admite analogia em desfavor do réu. No entanto, a Lei Maria da Penha já foi aplicada à mulher transexual por decisão da $1^{\text {a }}$ Vara Criminal da Comarca de Anápolis, em Goiás, da lavra da juíza Ana Claudia Veloso Magalhães (Processo n. 201103873908, TJ-GO) (MELLO, 2019, p. 144)" Cumpre mencionar que tal decisão é de extrema relevância, pois mostra que o termo "mulher" vem ganhando sentido amplo, e as leis estão sendo aplicadas de maneira extensiva a todas as mulheres, sejam elas transexuais ou nascidas biologicamente com o cromossomo feminino.

Entretanto em que pese a Lei Maria da Penha já ter sido aplicada a transexuais, a aplicação da qualificadora do feminicídio ainda gera muita discussão no mundo jurídico. Uma parte da doutrina entende que a Lei deverá ser aplicada apenas às mulheres que pertencem ao critério biológico, já outra parte da doutrina entende que a Lei deve ser aplicada de forma extensiva e que deve abranger também as transexuais. A respeito do tema, Diego Luiz Victório Pureza (2015, p. 4) comenta:

Fruto de uma doutrina conservadora, uma primeira corrente defende que o transexual não pode figurar como vítima do feminicídio, uma vez que, apesar de passar por cirurgia de mudança de sexo tendo seu órgão genital alterado em conformidade com sua identidade de gênero psíquico, geneticamente não é mulher. Ou seja, leva-se em consideração apenas o critério biológico para a configuração do feminicídio. Em sentido contrário, uma corrente considerada moderna entende ser perfeitamente possível que um transexual seja vítima de feminicídio, desde que altere o sexo de forma permanente (cirurgia de mudança de sexo irreversível). De acordo com esta corrente, o transexual deve ser tratado conforme sua atual realidade morfológica, coadunando-se, inclusive, com o atual entendimento jurisprudencial no qual admite a alteração do registro civil. Diversamente da corrente anterior, leva-se em consideração os critérios biológico e jurídico.

Por fim, temos uma terceira posição doutrinária que se refere ao critério jurídico civil, ou seja, o sexo que consta no registro civil. Importante mencionar que este critério pode ser vinculado tanto ao critério biológico quanto ao critério psicológico, pois também temos julgados que reconhecem que os transexuais podem ser considerados mulheres, mesmo sem a cirurgia de redesignação de gênero.

Nesse sentido, importante mencionar recente julgado do Superior Tribunal de Justiça (Recurso Especial 1626739/RS), de relatoria do Ministro Luís Felipe Salomão, Quarta Turma, julgado em 09/05/2017, DJe 01/08/2017). Nessa decisão, o magistrado considerou a possibilidade de uma mulher transgênero modificar seu nome de nascença, mesmo sem a cirurgia de redesignação de gênero e afirmou que tal decisão se pauta principalmente na dignidade da pessoa humana, que é um dos mais importantes princípios da Constituição Federal Brasileira. 
Por fim cabe mencionar que o Decreto $\mathrm{n}^{\circ}$ 65.127, de 12 de agosto de 2020, alterou o Decreto $n^{\circ} 29.981$, de $1^{\circ}$ de junho de 1989, que estabelece as atribuições e competências no âmbito das Delegacias de Polícia de Defesa da Mulher em São Paulo, substituindo o termo "sexo feminino" por "gênero feminino", o que reforça a extensão do conceito de mulher nos dias atuais para fins de aplicação das leis que a protege.

\section{FEMINICÍDIO E LEGISLAÇÃO}

Em 2013, uma Comissão Parlamentar Mista de Inquérito foi formada para tratar e investigar a situação de violência contra a mulher nos estados brasileiros e "apurar denúncias de omissão por parte do poder público com relação à aplicação de instrumentos instituídos em lei para proteger as mulheres em situação de violência" (Comissão Parlamentar Mista de Inquérito, 2013, p. 1). Tal processo durou cerca de um ano e teve entre algumas outras propostas de mudança:

Acrescentar parágrafo $7^{\circ}$ ao art.121, criando a agravante de feminicídio, como uma forma extrema de violência de gênero contra as mulheres, que se caracteriza pelo assassinato da mulher quando presentes circunstâncias de violência doméstica e familiar, violência sexual ou mutilação ou desfiguração da vítima. (Comissão Parlamentar Mista de Inquérito, 2013, p. 998).

E assim, após a aprovação do Projeto de Lei 8305/2014, de autoria do Senado Federal - CPMI Violência Contra a Mulher no Brasil, foi sancionada a Lei 13.104/ 2015 conhecida como Lei do Feminicídio. A mencionada lei entrou em vigor no dia 9 de março de 2015 e prevê o feminicídio como circunstância qualificadora do crime de homicídio.

[...] de autoria da Comissão Parlamentar Mista de Inquérito da Violência Contra a Mulher. Com a sanção presidencial, o assassinato de mulher por razões de gênero (quando envolve violência doméstica familiar ou menosprezo e discriminação à condição de mulher) passa a ser incluído entre os tipos de homicídio qualificado. (MELLO, 2019, p. 141).

O feminicídio é o homicídio doloso praticado contra a mulher por condição do sexo feminino, segundo o Código Penal.

A Comissão Parlamentar Mista de Inquérito (CPMI-VCM) conceitua o feminicídio como (2013, p. 1003):

O assassinato de mulheres pela condição de serem mulheres é chamado de "feminicídio" - sendo também utilizados os termos "feminicídio" ou "assassinato relacionado a gênero" - e se refere a um crime de ódio contra as mulheres, justificada socioculturalmente por uma história de dominação da mulher pelo homem e estimulada pela impunidade e indiferença da sociedade e do Estado. Conforme o Relato Temático sobre Feminicídio da Relatora Especial Rashida Manjoo, “antes de configu- 
rar uma nova forma de violência, assassinatos relacionados a gênero são a manifestação extrema de formas existentes de violência contra as mulheres". Tais assassinatos não são incidentes isolados que surgem repentina e inesperadamente, mas sim o ato último da violência contra as mulheres, experienciada como um contínuo de violência. [...]

O feminicídio é a instância última de controle da mulher pelo homem: o controle da vida e da morte. Ele se expressa como afirmação irrestrita de posse, igualando a mulher a um objeto, quando cometido por parceiro ou ex-parceiro; como subjugação da intimidade e da sexualidade da mulher, por meio da violência sexual associada ao assassinato; como destruição da identidade da mulher, pela mutilação ou desfiguração de seu corpo; como aviltamento da dignidade da mulher, submetendo-a a tortura ou a tratamento cruel ou degradante. (BRASIL, 2013, p. 1003).

Como se vê, o feminicídio é o último ato de violência praticado contra a mulher, encerrando um círculo de contínuas agressões.

A Lei 13.104/2015, alterou a redação do artigo 121 do Código Penal Brasileiro e incluiu em seu $\S 2^{\circ}$, inciso, VI a qualificadora do feminicídio in verbis:

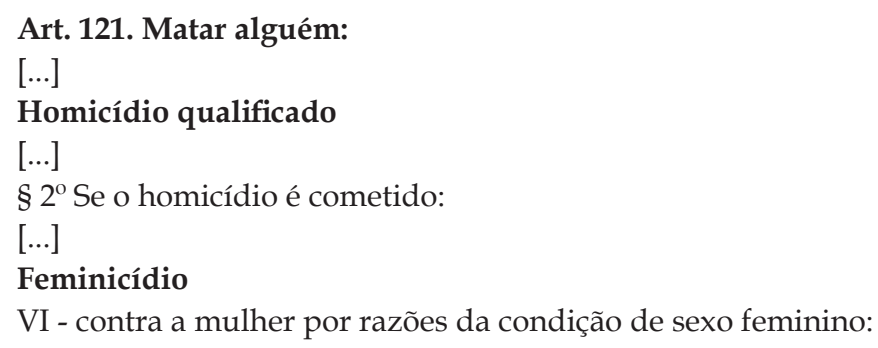

No que tange às causas de aumento da pena previstas no $\S 7^{\circ}$, inciso I, do artigo 121 do Código Penal, Adriana Ramos de Mello explica que (2019, p. 147):

Deve se observar desde logo que é necessário que tais circunstâncias tenham ingressado na esfera de conhecimento do agente. Ou seja, o agente tem de ter conhecido da gestação, ou que, há três meses, a vítima tenha realizado seu parto. Caso contrário, ou seja, se tais fatos não eram 
do conhecimento do agente será impossível aplicar a causa de aumento da pena.

\section{Quanto aos incisos II e III do $\S 7^{\circ}$, do artigo 121 do Código Penal, Mello pontua que (2019, p149):}

Exige-se que o agente tenha conhecimento da situação de portador de deficiência da vítima, sob pena de não incidir a causa de aumento de pena (em virtude do erro de tipo).

$[\ldots]$

Já se o crime, ao ser perpetrado na presença de descendente ou ascendente da vítima, adquire uma reprovação ainda maior, pois trará um trauma muito intenso para o familiar que o assistiu; marca que, muitas vezes, acompanhará a pessoa para toda a sua vida. [...] é preciso também que haja prova do parentesco nos autos, produzida através de documentos necessários (certidão de nascimento, documento de identidade etc.).

Já no que se refere às causas de diminuição da pena, Amom Albernaz Pires assevera (2015, p.7 e 8):

No que diz respeito à redação dos quesitos a serem votados na sala especial pelos jurados nos casos de feminicídio, não se pode olvidar que o parágrafo único do art. 482 do CPP determina que os quesitos sejam redigidos em proposições afirmativas, simples e distintas, de modo que cada um deles possa ser respondido com suficiente clareza e necessária precisão. Desse modo, o quesito da qualificadora do feminicídio, assim como os das causas de aumento trazidas pelo novel $\S 7^{\circ}$ do art. 121 do $\mathrm{CP}$ deverão ser votados por último, após os quesitos da materialidade, autoria, absolvição e eventual quesito de causa de diminuição de pena alegada pela defesa. (CPP, art. 483).

Já no que concerne à classificação da qualificadora do feminicídio temos um tema muito debatido entre os juristas, pois uns entendem se tratar de uma qualificadora subjetiva, já outros entendem que seja objetiva. No entendimento de Guilherme Souza Nucci (2017, p. 87):

Trata-se de uma qualificadora objetiva, pois se liga ao gênero da vítima: ser mulher. Historicamente, sempre predominou o androcentrismo, colocando o homem no centro de tudo, em oposição à misoginia, justificando um ódio às mulheres, mais fracas fisicamente e sem condições de ascensão social. Não aquiescemos à ideia de ser uma qualificadora subjetiva (como o motivo torpe ou fútil) somente porque se inseriu a expressão "por razões de condição de sexo feminino". Não é essa a motivação do homicídio. O agente não mata a mulher somente porque ela é mulher, mas o faz por ódio, raiva, ciúme, disputa familiar, prazer, sadismo, enfim, motivos variados, que podem ser torpes ou fúteis; podem, inclusive, ser moralmente relevantes. Não se descarta, por óbvio, 
a possibilidade de o homem matar a mulher por questões de misoginia ou violência doméstica; mesmo assim, a violência doméstica e a misoginia proporcionam aos homens o prazer de espancar e matar a mulher, porque esta é fisicamente mais fraca. É o que se chama de violência de gênero, o que nos parece objetivo - e não subjetivo.

O egrégio Tribunal de Justiça do Rio Grande do Sul também tem o entendimento de que a qualificadora é objetiva. Vejamos recente acórdão proferido pelo Tribunal:

Ementa: PRONÚNCIA. HOMICÍDIO. FEMINICÍDIO. QUALIFICADORA MANTIDA. Correta a decisão da maioria em manter, na pronúncia, a qualificadora do feminicídio. Como destacou o voto condutor da maioria, "referida causa qualificativa reúne indícios suficientes para ser acolhido pela decisão de pronúncia, e isso se dá exatamente porque é uma qualificadora de ordem objetiva - vai incidir sempre que o crime estiver atrelado à violência doméstica e familiar propriamente dita -, e existem indicativos de que o crime tenha ocorrido na forma descrita na denúncia, ou seja, logo após a vítima e o réu saírem de uma audiência pelo procedimento Maria da Penha, já que, na época dos fatos, estavam em processo de separação, após relacionamento que perdurou por 18 anos." DECISÃO: Embargos infringentes rejeitados. Por maioria. (Embargos Infringentes e de Nulidade, $N^{\circ} 70077233740$, Primeiro Grupo de Câmaras Criminais, Tribunal de Justiça do RS, Relator: Sylvio Baptista Neto, Julgado em: 04-05-2018)

No entendimento dos juristas Alice Bianchini e Luiz Flávio Gomes, trata-se de uma qualificadora subjetiva. Os autores explicam (2015, p. 22):

A qualificadora do feminicídio é nitidamente subjetiva. Sabe-se que é possível coexistência das circunstâncias privilegiadoras ( $\S 1^{\circ}$ do art. 121), todas de natureza subjetiva, com qualificadoras de natureza objetiva ( $\S$ $2^{\circ}$, III e IV). Quando se reconhece (no júri) o privilégio (violenta emoção, por exemplo), crime, fica afastada, automaticamente, a tese do feminicídio (posição de Rogério Sanches, que compartilhamos). É impossível pensar num feminicídio, que é algo abominável, reprovável, repugnante à dignidade da mulher, que tenha sido praticado por motivo de relevante valor moral ou social ou logo após injusta provocação da vítima. Uma mulher usa minissaia. Por esse motivo fático o seu marido ou namorado lhe mata. E mata por uma motivação aberrante de achar que a mulher é de sua posse, que a mulher é objeto, que a mulher não pode contrariar as vontades do homem. Nessa motivação há uma ofensa à condição de sexo feminino. O sujeito mata em razão da condição do sexo feminino. Em razão disso, ou seja, por causa disso. Seria uma qualificadora objetiva se dissesse respeito ao modo ou meio de execução do crime. A violência de gênero não é uma forma de execução do crime, sim, sua razão, seu motivo. Por isso que é subjetiva.

Nesse mesmo sentido, Rogério Sanches de Cunha entende que se trata de uma qualificadora subjetiva. Nos dizeres do autor (2017, p. 347): 
a qualificadora do feminicídio é subjetiva, pressupondo motivação especial: o homicídio deve ser cometido contra a mulher por razão das condição de sexo feminino. Mesmo no caso do inciso I do $\S 2^{\circ}-\mathrm{A}$, o fato de a conceituação de violência doméstica e familiar ser um dado objetivo, extraído da lei, não afasta a subjetividade. Isso porque o $\S 2^{\circ}$-A é apenas explicativo; a qualificadora está verdadeiramente no inciso VI, que, ao estabelecer que o homicídio se qualifica quando cometido por razões da condição do sexo feminino, evidente que isso ocorre pela motivação, não pelos meios de execução.

Ortega comenta que antes da entrada em vigor da lei que qualificou o feminicídio, os crimes cometidos contra as mulheres poderiam ser enquadrados em algum dos casos previstos no artigo 121 do Código Penal (2016, p.1):

\begin{abstract}
A depender do caso concreto, o feminicídio (mesmo sem ter ainda este nome) poderia ser enquadrado como sendo homicídio qualificado por motivo torpe (inciso I do $\S 2^{\circ}$ do art. 121) ou fútil (inciso II) ou, ainda, em virtude de dificuldade da vítima de se defender (inciso IV). No entanto, o certo é que não existia a previsão de uma pena maior para o fato de o crime ser cometido contra a mulher por razões de gênero.
\end{abstract}

Cabe mencionar que no crime de feminicídio o sujeito ativo pode ser tanto mulheres quanto homens, pois a lei não faz nenhuma distinção a respeito dos agressores. No entanto o crime só será enquadrado na qualificadora do feminicídio quando cometido contra a mulher e em razão de seu gênero.

Ainda relativamente à Lei do Feminicídio cabe destacar um fato de extrema relevância que ocorreu no dia 06 de novembro de 2019. Por unanimidade de votos foi aprovada a PEC (Proposta de Emenda à Constituição) 75/2019, que torna tanto o crime de feminicídio como o de estupro imprescritíveis. $O$ texto agora foi encaminhado à Câmara dos Deputados para votação.

O projeto, de autoria da senadora Rose de Freitas objetiva alterar o artigo $5^{\circ}$ da $\mathrm{CF} / 88$ para determinar que o crime enquadrado como feminicídio poderá ser julgado a qualquer tempo, independentemente da data em que tenha sido cometido.

$[\ldots]$

Na justificação da PEC 75/19, a senadora cita estudo da OMS - Organização Mundial da Saúde que situou o Brasil em quinto lugar na taxa de feminicídios entre 84 nações pesquisadas. A senadora também menciona o Mapa da Violência de 2015, segundo o qual 106 mil mulheres foram assassinadas no país entre 1980 e 2013. Na CCJ do Senado, a proposta foi relatada pelo senador Alessandro Vieira, que deu parecer favorável ao texto. Ele também incluiu o estupro na lista de crimes imprescritíveis, o que também está previsto em outra proposta - a PEC 64/16 -, que já foi aprovada no Senado e aguarda decisão da Câmara dos Deputados. (MIGALHAS, 2019, p.1). 


\section{PERFIL DAS VÍTIMAS}

Para analisar o perfil das principais vítimas do crime de feminicídio, utilizaremos como base pesquisas quantitativas divulgadas nos anos 2018 a 2019.

No ano de 2018, segundo o Instituto de Segurança Pública do Rio de Janeiro, a maioria das vítimas da qualificadora do feminicídio tinha como principais características:

Figura 1 - Características das vítimas de feminicídio no Rio de Janeiro em 2018
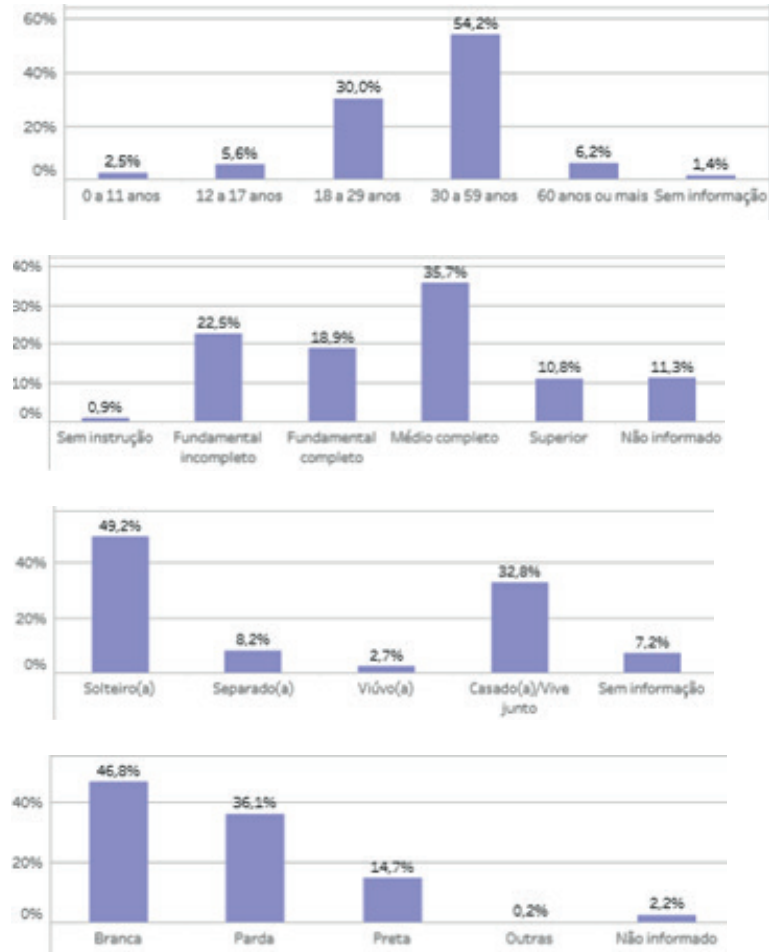

Fonte: Instituto de Segurança Pública do Rio de Janeiro (2018)

No que diz respeito ao ano de 2018 é possível observar que grande parte das vítimas de feminicídio tinha a idade entre 30 e 59 anos (54,2\%), seu nível de escolaridade era o ensino médio completo $(35,7 \%)$, a maioria era solteira $(49,2 \%)$ e tinha a cor da pele branca $(46,8 \%)$.

No mais, vamos estudar também os dados divulgados pelo Anuário Brasileiro de Segurança Pública 2019. Cumpre mencionar que embora a pesquisa tenha sido divulgada em 2019 os dados se referem aos anos de 2017 e 2018: 
Figura 2 - Cor/Raça das vítimas de feminicídio no Brasil

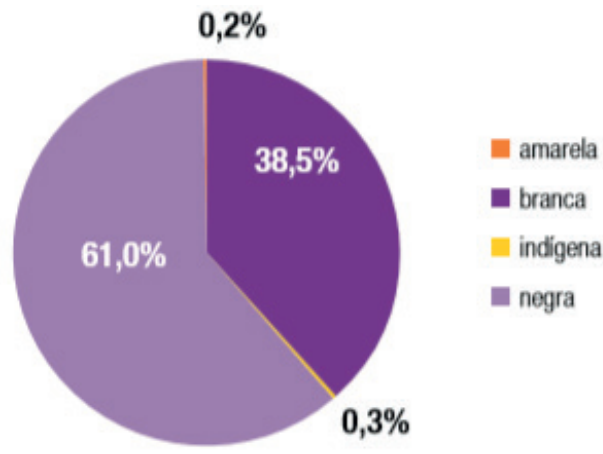

Fonte: Fórum Brasileiro de Segurança Pública (2019)

Vejamos, segundo os dados referentes à figura 2: as mulheres negras representam mais da metade das vítimas de feminicídio (61,0\%). Entretanto cabe mencionar que, segundo os dados divulgados pelo Instituto de Segurança Pública do Rio de Janeiro (figuras 1 desta pesquisa), as mulheres brancas foram as mais atacadas, seguidas das mulheres pardas que não aparecem nesse gráfico. Ou seja, é possível que quando o perfil das vítimas foi analisado, tendo em conta apenas um estado, as mulheres que possuíam a cor de pele branca eram as principais vítimas. Porém, quando foi feita a análise referente a todos os estados as mulheres negras somaram a maioria das vítimas do feminicídio.

Observemos agora, os dados referentes à idade das vítimas.

Figura 3 - Idade das vítimas de feminicídio no Brasil

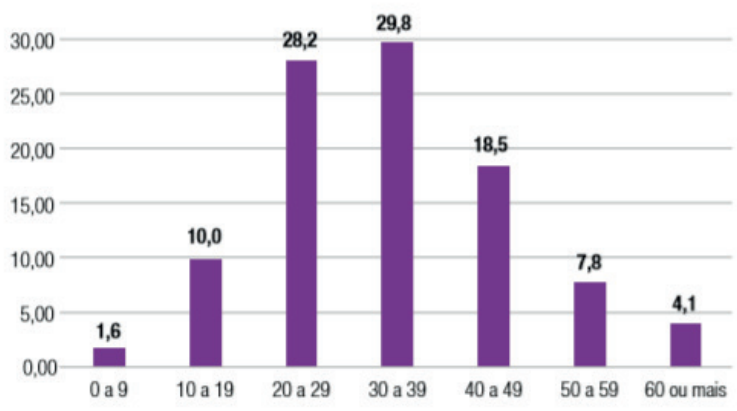

Fonte: Fórum Brasileiro de Segurança Pública (2019)

Nesta figura é possível verificar que as mulheres entre 20 a $29(28,2 \%)$ anos e 30 a $39(29,8 \%)$ formaram quase a mesma porcentagem de vítimas.

No que diz respeito ao nível de escolaridade, as mulheres que possuem apenas o ensino fundamental foram as principais vítimas do crime de homicídio em razão do gênero feminino, representando $70,7 \%$ das mortes. 
Figura 4 - nível de escolaridade das vítimas de feminicídio no Brasil

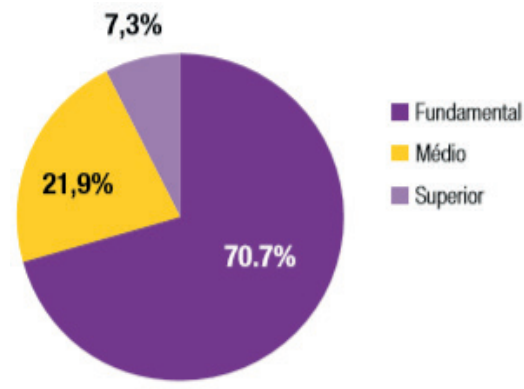

Fonte: Fórum Brasileiro de Segurança Pública (2019)

Nota-se que as mulheres que possuem apenas o ensino fundamental se sobrepõem muito em relação aos outros níveis de escolaridade.

Diante dos dados apresentados, foi possível notar que entre os anos de 2018 e 2019 as principais vítimas do crime de feminicídio tinham como principais características idade de 30 anos ou mais, nível de escolaridade ensino fundamental e médio. Em todos os dados analisados as mulheres eram solteiras e pôr fim a cor/ raça das mulheres teve como prevalência a cor negra e branca.

\section{PERFIL DOS CRIMINOSOS E SUAS MOTIVAÇÕES}

A análise aqui também será feita com base em pesquisas quantitativas divulgadas entre os anos de 2018 e 2019.

No que se refere ao ano de 2018, o Instituto de Segurança Pública do Rio de Janeiro também publicou o Dossiê Mulher 2019 (2019, p. 18), onde consta:

Em mais da metade dos homicídios dolosos de mulheres não se tem registro da relação entre autor e vítimas (58,5\%), informação de grande importância para compreender os fatores de proximidade agressor-vítima que envolveram as mortes destas mulheres. É muito comum, nos casos de homicídios, este tipo de informação só ser identificado ao longo do inquérito policial, pois nem sempre a identificação do suspeito ocorre em tempo hábil para que tal informação seja incluída no registro de ocorrência. Mesmo assim, é bastante expressivo que companheiros e ex-companheiros tenham sido os autores de 12,3\% dos homicídios dolosos de mulheres no estado do Rio de Janeiro. Grande parte dos homicídios dolosos de mulheres ocorreram no interior de residência (34,3\%), totalizando 120 vítimas. Ainda quanto ao local do fato, via pública foi o que apareceu de forma mais recorrente nos registros. $(41,4 \%)$.

Em que pese, a pesquisa informar que muitas vezes não é possível identificar a relação entre o autor do crime e a mulher, namorados, maridos, companheiros sejam eles ex ou atual sempre estão envolvidos nas agressões, seguidos de conhecidos, parentes e por fim desconhecidos. 
Quanto ao ano de 2018, a pesquisa ainda divulgou os seguintes dados:

Figura 5 - Vínculo do agressor com as vítimas do crime de feminicídio e local do crime

\begin{tabular}{|lcc|}
\hline & Na $^{2}$ abs. & Distribuição (95) \\
\hline Relação autor-vitima & 350 & 100,0 \\
\hline Ex ou companheiros & 43 & 12,3 \\
\hline Pais ou padrastos & 1 & 0,3 \\
\hline Parentes & 9 & 2,6 \\
\hline Conhecidos & 6 & 1,7 \\
\hline Outros & 9 & 2,6 \\
\hline Nenhuma & 77 & 22,0 \\
\hline Nảo informado & 205 & 58,5 \\
\hline Tipo de local do fato & 350 & 100,0 \\
\hline Residẻncia & 120 & 34,3 \\
\hline Via pública & 145 & 41,4 \\
\hline Interior de transporte coletivo/alternativo & 3 & 0,9 \\
\hline Outros locais & 58 & 16,6 \\
\hline Nảo informado & 24 & 6,8 \\
\hline
\end{tabular}

Instituto de Segurança Pública do Rio de Janeiro, Dossiê Mulher (2019)

O Dossiê Mulher informou que as vítimas do crime de feminicídio foram mortas por desconhecidos, ou ainda por seus companheiros ou ex-companheiros. No que se refere ao local dos fatos, a residência das vítimas e locais públicos continuam sendo as principais áreas que ocorreram o crime.

Com relação ao ano de 2019, utilizaremos os dados fornecidos pelo Anuário Brasileiro de Segurança Pública 2019. Cabe frisar que, embora a pesquisa tenha sido divulgada no ano de 2019, tais dados se referem a informações colhidas entre os anos de 2017 e 2018.

Retomando aos dados divulgados pelo Anuário Brasileiro de Segurança Pública 2019, a pesquisa informou que os agressores em sua maioria são companheiros ou ex-companheiros da vítima, representando $88,8 \%$ das pessoas que cometeram o crime de feminicídio, seguido de pessoas que possuem outro vínculo $(9,4 \%$ ), parentes $(1,3 \%)$ e conhecidos $(0,5 \%)$.

O Anuário Brasileiro de Segurança Pública ainda pontuou que:

A relação próxima com o algoz é apontada por diversos estudos de vitimização como característica marcante das violências de gênero. Este aspecto relaciona- -se com a amplitude característica da violência contra a mulher, que incide nas relações íntimas conjugais através da dependência patrimonial e violência psicológica, por exemplo. São traços desafiadores das políticas de prevenção e proteção, pois ocorrem no seio de relações das quais se espera segurança e confiança, e que comumente estão investidas de tabus por dizerem respeito à esfera doméstica e familiar. Não à toa, muitos dos casos de feminicídios registrados nos últimos anos e registrados pela imprensa tratavam de mulheres que 
buscavam a separação do agressor. De acordo com as Diretrizes para investigar, processar e julgar com perspectiva de gênero as mortes violentas de mulheres são condições estruturais das mortes violentas de mulheres por razões de gênero: o sentimento de posse, o controle sobre o corpo e autonomia da mulher, a limitação da emancipação profissional, econômica, social e intelectual da mulher, seu tratamento como objeto sexual e a manifestação de desprezo e ódio pela mulher. (Anuário Brasileiro de Segurança Pública, 2019, p. 113)

A respeito de tais informações é possível, mais uma vez, afirmar que tais comportamentos nos remetem aos padrões patriarcais, ou seja, os homens ainda acreditam ter poder e domínio sobre as mulheres.

Vejamos ainda a figura que demonstra os dados referentes à relação da vítima com o autor do crime de feminicídio.

Figura 6- Vínculo do agressor com as vítimas do crime de feminicídio

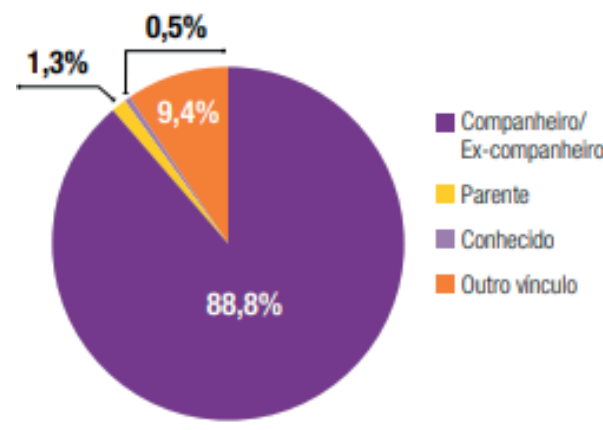

Fonte: Anuário Brasileiro de Segurança Pública (2019)

Cabe mencionar ainda que a pesquisa informou que geralmente os crimes ocorrem na residência das vítimas $(65,6 \%)$ ou em vias públicas $(22,2)$. Observemos:

Figura 7 - Local da morte das vítimas de feminicídio

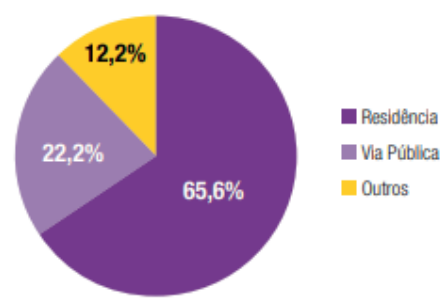

Fonte: Anuário Brasileiro de Segurança Pública (2019)

Referente ao perfil dos criminosos foi possível notar primeiramente que as pesquisas não divulgam informações referentes ao grau de escolaridade, idade 
e cor/raça dos criminosos. Os dados que são divulgados referentes ao perfil dos homens que cometem homicídio contra as mulheres evidenciam que estão mais relacionados ao grau de parentesco ou vínculo que os agressores possuíam com as vítimas. No caso do feminicídio foi possível notar que em todos os casos a maioria dos homens possuía algum tipo de relacionamento amoroso com as mulheres.

Quanto às motivações do crime, é fato que os principais motivos são a busca incessante do homem em demonstrar que "comanda" a relação, o sentimento de posse com a mulher e a negação em aceitar o fim do relacionamento. Ou seja, o principal ponto que leva os homens a cometerem o crime de feminicídio está relacionado ao fato de que eles não aceitam que suas mulheres tenham autonomia ou estejam de igual para igual com eles dentro de suas relações.

\section{ESTATÍSTICAS ANTES E APÓS A TIPIFICAÇÃO DO CRIME DE FE- MINICÍDIO NO CÓDIGO PENAL}

Analisaremos agora as estatísticas do crime de feminicídio antes e após a entrada em vigor da Lei $\mathrm{n}^{\circ} 13.104$ em 2015, que tipificou o crime como qualificadora do homicídio doloso no Código Penal Brasileiro em seu artigo 121, § $2^{\circ}$, inciso VI.

Utilizaremos como parâmetro para estudo os anos de 2006 e 2014 a 2019 cabe mencionar que analisaremos as estatísticas desde 2006, pois foi o ano em que entrou em vigor a Lei 11.104/2006, mais conhecida como Lei Maria da Penha, que também é um grande marco jurídico de enfrentamento no combate à violência contra a mulher.

Em 2018, o Senado Federal publicou a segunda edição de uma pesquisa quantitativa que realizou, intitulada Panorama da Violência Contra as Mulheres no Brasil Indicadores Nacionais e Estaduais, que tem por objetivo

a partir da compilação e análise de distintos indicadores, oferecer uma atualização do cenário da violência contra as mulheres, bem como das ações governamentais que têm por objeto seu enfrentamento, no Brasil e em suas unidades federativas (Senado Federal, 2018, p.5).

Ou seja, tal pesquisa tem o objetivo de analisar como estão os índices de violência no Brasil e as ações que o governo está tomando em relação aos crimes que foram praticados.

A figura que será analisada a seguir, produzida pelo Senado Federal (2018, p. 8), traz

as taxas de homicídio de mulheres, por estado, calculadas a partir dos dados registrados no Sistema de Informações sobre Mortalidade (SIM) do Ministério da Saúde (MS), referentes aos anos de 2006 (ano de promulgação da Lei Maria da Penha), 2014 e 2015.

Notemos que tais informações são de suma importância, pois demonstraram os dados de todos os estados brasileiros; além disso, cabe mencionar que a figura também destaca a cor/raça das vítimas. Analisemos os dados divulgados: 
Tabela 1 - Taxa de homicídio por 100 mil mulheres

\begin{tabular}{|c|c|c|c|c|c|c|c|c|c|}
\hline \multicolumn{10}{|c|}{ Tabela - Taxas de Homicídio por $100 \mathrm{mil}$ mulheres } \\
\hline \multirow[t]{2}{*}{ UF } & \multicolumn{3}{|c|}{$\begin{array}{c}\text { Taxas de homicídios de } \\
\text { mulheres de todas as } \\
\text { raças }\end{array}$} & \multicolumn{3}{|c|}{$\begin{array}{l}\text { Taxas de homicídios } \\
\text { de mulheres brancas }\end{array}$} & \multicolumn{3}{|c|}{$\begin{array}{l}\text { Taxas de homicídios de mu- } \\
\text { lheres pretas e pardas }\end{array}$} \\
\hline & 2006 & 2014 & 2015 & 2006 & 2014 & 2015 & 2006 & 2014 & 2015 \\
\hline $\mathrm{AC}$ & 4,5 & 5,1 & 4,7 & 6,4 & 4,6 & 4,6 & 3,3 & 5,4 & 4,7 \\
\hline $\mathbf{A P}$ & 4,2 & 5,3 & 4,7 & 3,7 & 1,1 & 3,1 & 4,3 & 6,7 & 4,5 \\
\hline AM & 3,2 & 4,1 & 5,9 & 2,8 & 2,0 & 1,5 & 2,7 & 4,4 & 6,4 \\
\hline PA & 3,8 & 6,1 & 6,4 & 2,4 & 2,2 & 2,4 & 4,2 & 7,0 & 7,3 \\
\hline RO & 6,6 & 6,4 & 7,2 & 7,0 & 5,4 & 4,7 & 6,3 & 6,5 & 8,2 \\
\hline RR & 6,4 & 9,5 & 11,4 & 9,9 & 1,8 & 3,8 & 1,9 & 5,5 & 5,2 \\
\hline TO & 3,6 & 4,7 & 6,1 & 2,5 & 3,5 & 3,4 & 3,7 & 5,0 & 6,5 \\
\hline AL & 6,7 & 7,4 & 5,4 & 1,0 & 0,8 & 0,2 & 6,6 & 10,0 & 7,1 \\
\hline BA & 3,3 & 4,9 & 4,9 & 1,4 & 2,9 & 2,5 & 3,4 & 5,2 & 5,3 \\
\hline CE & 3,1 & 6,3 & 5,5 & 1,2 & 1,7 & 1,6 & 2,3 & 4,6 & 4,8 \\
\hline MA & 2,0 & 4,2 & 4,3 & 0,9 & 3,0 & 3,3 & 2,4 & 4,5 & 4,2 \\
\hline PB & 3,3 & 5,5 & 5,3 & 1,4 & 1,5 & 1,5 & 4,3 & 7,5 & 6,7 \\
\hline PE & 6,9 & 5,0 & 4,8 & 2,1 & 1,9 & 2,1 & 9,4 & 6,5 & 6,2 \\
\hline PI & 2,0 & 3,8 & 4,0 & 1,0 & 1,0 & 2,0 & 2,4 & 4,1 & 4,3 \\
\hline $\mathbf{R N}$ & 2,6 & 5,9 & 5,1 & 1,5 & 3,0 & 1,1 & 2,7 & 7,1 & 7,1 \\
\hline SE & 4,1 & 6,4 & 6,1 & 2,8 & 3,0 & 1,3 & 3,3 & 7,7 & 7,7 \\
\hline ES & 10,3 & 6,9 & 6,9 & 5,6 & 2,8 & 2,7 & 10,3 & 9,2 & 9,2 \\
\hline MG & 3,9 & 3,7 & 3,8 & 3,0 & 3,0 & 3,0 & 4,5 & 4,3 & 4,3 \\
\hline RJ & 6,1 & 5,3 & 4,4 & 4,8 & 3,9 & 3,6 & 7,4 & 6,3 & 5,0 \\
\hline SP & 3,7 & 2,7 & 2,4 & 3,6 & 2,6 & 2,4 & 3,8 & 2,7 & 2,4 \\
\hline PR & 4,7 & 5,0 & 4,2 & 4,9 & 5,6 & 4,8 & 3,6 & 3,7 & 2,9 \\
\hline RS & 2,9 & 4,3 & 4,8 & 2,8 & 4,1 & 4,7 & 3,1 & 4,7 & 4,9 \\
\hline SC & 3,0 & 3,2 & 2,9 & 2,6 & 2,9 & 2,7 & 4,2 & 4,1 & 4,3 \\
\hline DF & 4,4 & 5,2 & 4,6 & 1,7 & 2,5 & 2,5 & 6,5 & 7,2 & 6,2 \\
\hline GO & 4,7 & 8,4 & 7,3 & 3,6 & 5,5 & 5,4 & 5,3 & 10,4 & 8,5 \\
\hline MT & 5,0 & 7,0 & 7,4 & 5,5 & 5,9 & 5,3 & 4,8 & 7,5 & 8,6 \\
\hline MS & 4,7 & 6,3 & 4,3 & 3,9 & 3,8 & 2,9 & 4,3 & 6,6 & 5,4 \\
\hline BRASIL & 4,2 & 4,6 & 4,4 & 3,3 & 3,2 & 3,0 & 4,6 & 5,4 & 5,2 \\
\hline
\end{tabular}

Fonte: Sistema de Informações sobre Mortalidade (SIM) do Ministério da Saúde (MS) e Senado Federal (2018)

É possível notar pela tabela 1 que, no ano de 2015, houve redução das taxas de homicídio de mulheres, tanto de cor/raça branca quanto pretas e pardas. Entretanto o Senado Federal ressaltou que (2018, p. 9): 
Contudo é importante destacar que, embora tenha sido verificada uma redução da taxa de homicídios de mulheres no último ano, tal taxa $(4,4)$ ainda se apresenta em um nível mais elevado do que o verificado em 2006 (4,2), ano de início da Lei Maria da Penha.

[...]

Verifica-se, ainda, que a violência letal atinge de forma diferente as mulheres a depender de sua raça, uma vez que, enquanto a taxa de homicídios de mulheres brancas em 2015 foi de 3,0 a mesma taxa entre as mulheres pretas e pardas foi de 5,2.

A mencionada pesquisa ainda informou que (2018, p.10):

Ao se levar em consideração as taxas de homicídios de mulheres registradas em cada estado no ano de 2015, verifica-se uma grande diversidade relativa aos níveis de violência letal contra as mulheres. [...] estados como São Paulo $(2,4)$ e Santa Catarina $(2,9)$, apresentaram taxas e homicídios de mulheres inferiores à taxa verificada no Brasil $(4,4$ homicídios por cem mil mulheres)

Observemos tais informações em gráfico divulgado pelo Sistema de Informações sobre Mortalidade (SIM), do Ministério da Saúde (MS) e Senado Federal:

Figura 8 - taxa de mulheres por estado em 2015

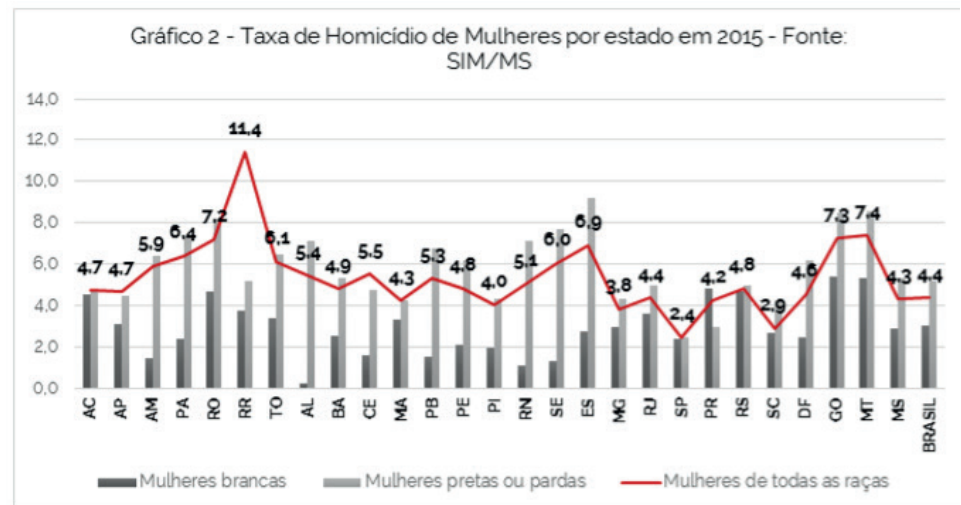

Fonte: Sistema de Informações sobre Mortalidade (SIM) do

Ministério da Saúde (MS) e Senado Federal (2018)

A partir da análise da figura 8, é possível notar que os estados de Roraima, Mato Grosso, Goiás e Rondônia, tiverem os maiores índices de feminicídio no ano de 2015.

No que se refere aos anos de 2006 e 2014 a 2015, é possível notar que houve aumento e, posteriormente, declínio no número de mulheres mortas em razão de seu gênero nos estados; além disso foi possível observar também que em alguns estados os números são explicitamente mais altos. Passemos agora a analisar as estatísticas referentes ao ano de 2016. 
O Instituto de Pesquisa Econômica Aplicada (IPEA) e o Fórum Brasileiro de Segurança Pública publicaram em 2018 o Atlas da Violência e, a respeito do número de mulheres assassinadas entre os anos de 2006 e 2016, fez a seguinte afirmação $(2018$, p. 44):

Em 2016, 4.645 mulheres foram assassinadas no país, o que representa uma taxa de 4,5 homicídios para cada 100 mil brasileiras. Em dez anos, observa-se um aumento de 6,4\% (tabelas 6.1 e 6.2). Chama a atenção que em 2016 o estado de Roraima apresentou uma taxa de 10 homicídios por 100 mil mulheres, com uma distância razoável dos estados com taxas mais próximas, Pará $(7,2)$ e Goiás $(7,1)$. As taxas de Roraima flutuam bastante ao longo da série histórica, mas chegaram a picos de 14,8 em 2013, 11,4 em 2015 e, com exceção de 2011, nos demais anos a taxa de homicídios de mulheres em Roraima foi superior à taxa brasileira.

Notemos que, assim como no ano de 2015, os estados de Roraima e Goiás são os locais onde os índices de feminicídio são maiores. Analisemos a seguir as tabelas 6.1 e 6.2 mencionadas pelo Atlas da Violência:

Figura 9 - Número de homicídios de mulheres por UF no Brasil (2006 a 2016)

\begin{tabular}{|c|c|c|c|c|c|c|c|c|c|c|c|}
\hline & 2006 & 2007 & 2008 & 2009 & 2010 & 2011 & 2012 & 2013 & 2014 & 2015 & 2016 \\
\hline Brasil & 4030 & 3778 & 4029 & 4265 & 4477 & 4522 & 4729 & 4769 & 4836 & 4621 & 4645 \\
\hline Acre & 15 & 18 & 13 & 16 & 19 & 18 & 16 & 32 & 20 & 19 & 23 \\
\hline Alagoas & 106 & 109 & 83 & 111 & 137 & 138 & 133 & 142 & 125 & 95 & 101 \\
\hline Amapá & 13 & 12 & 13 & 12 & 16 & 19 & 17 & 19 & 20 & 18 & 17 \\
\hline Amazonas & 53 & 52 & 63 & 67 & 65 & 81 & 118 & 96 & 80 & 115 & 116 \\
\hline Bahia & 243 & 249 & 315 & 345 & 438 & 449 & 437 & 423 & 385 & 382 & 441 \\
\hline Ceará & 134 & 126 & 117 & 138 & 173 & 189 & 219 & 278 & 285 & 254 & 218 \\
\hline Distrito Federal & 49 & 55 & 64 & 76 & 66 & 79 & 77 & 78 & 60 & 58 & 64 \\
\hline Espíito Santo & 183 & 186 & 190 & 216 & 174 & 167 & 163 & 171 & 140 & 141 & 104 \\
\hline Goiás & 143 & 139 & 160 & 165 & 182 & 262 & 247 & 271 & 290 & 255 & 238 \\
\hline Maranhão & 67 & 63 & 81 & 87 & 117 & 131 & 114 & 131 & 152 & 148 & 159 \\
\hline Mato Grosso & 70 & 95 & 86 & 94 & 80 & 87 & 100 & 91 & 111 & 118 & 104 \\
\hline Mato Grosso do Sul & 55 & 67 & 60 & 65 & 76 & 78 & 77 & 75 & 85 & 58 & 80 \\
\hline Minas Gerais & 392 & 403 & 377 & 402 & 409 & 457 & 460 & 427 & 403 & 415 & 375 \\
\hline Parń & 140 & 144 & 169 & 180 & 231 & 186 & 232 & 231 & 249 & 261 & 294 \\
\hline Paraiba & 62 & 69 & 87 & 98 & 119 & 140 & 137 & 126 & 117 & 111 & 107 \\
\hline Paraná & 249 & 241 & 306 & 331 & 338 & 283 & 321 & 283 & 284 & 244 & 238 \\
\hline Pernambuco & 310 & 290 & 298 & 304 & 247 & 261 & 216 & 256 & 239 & 233 & 282 \\
\hline Piaú & 32 & 35 & 38 & 31 & 40 & 32 & 46 & 47 & 63 & 67 & 50 \\
\hline Rio de Janeiro & 504 & 416 & 373 & 350 & 339 & 366 & 365 & 387 & 464 & 387 & 428 \\
\hline Rio Grande do Norte & 42 & 42 & 59 & 57 & 71 & 76 & 64 & 89 & 102 & 92 & 100 \\
\hline Rio Grande do Sul & 162 & 193 & 219 & 225 & 227 & 202 & 247 & 210 & 250 & 284 & 308 \\
\hline Rondônia & 51 & 28 & 39 & 51 & 37 & 48 & 51 & 52 & 56 & 63 & 54 \\
\hline Rornima & 13 & 19 & 15 & 24 & 11 & 10 & 17 & 36 & 24 & 29 & 25 \\
\hline Santa Catarina & 92 & 70 & 86 & 93 & 110 & 74 & 104 & 102 & 111 & 97 & 107 \\
\hline São Paulo & 788 & 595 & 667 & 660 & 678 & 580 & 640 & 620 & 612 & 559 & 507 \\
\hline Sergipe & 40 & 34 & 30 & 36 & 43 & 60 & 62 & 56 & 74 & 70 & 60 \\
\hline Tocantins & 22 & 28 & 21 & 31 & 34 & 49 & 49 & 40 & 35 & 48 & 45 \\
\hline
\end{tabular}

Fonte: Instituto de Pesquisa Econômica Aplicada (IPEA) e Fórum Brasileiro de Segurança Pública, Atlas da Violência (2018) 
A respeito da figura 9, o Atlas da Violência pontuou que (2018, p. 45):

Embora não estejam entre as UFs com as maiores taxas, quando se considera a década, Rio Grande do Norte e Maranhão tiveram os maiores aumentos, da ordem de 130\% (tabela 6.1). Já os estados com as menores taxas em 2016 foram São Paulo $(2,2)$, Piauí $(3,0)$ e Santa Catarina $(3,1)$. Desses três, apenas São Paulo apresentou queda na década, da ordem de $40,4 \%$. Em Santa Catarina, houve um aumento de 3,5\%, o que pode ser até uma indicação de estabilidade, dada a flutuação ao longo dos dez anos, enquanto no Piauí o aumento foi de $50 \%$. A maior queda pode ser verificada no estado do Espírito Santo (43,2\%), aparentemente uma tendência que se iniciou em 2014 (tabela 6.1).

Analisemos agora a segunda figura mencionada pelo Atlas da Violência:

Figura 10 - Taxa de homicídios de mulheres por 100 mil habitantes por UF no Brasil (2006 a 2016).

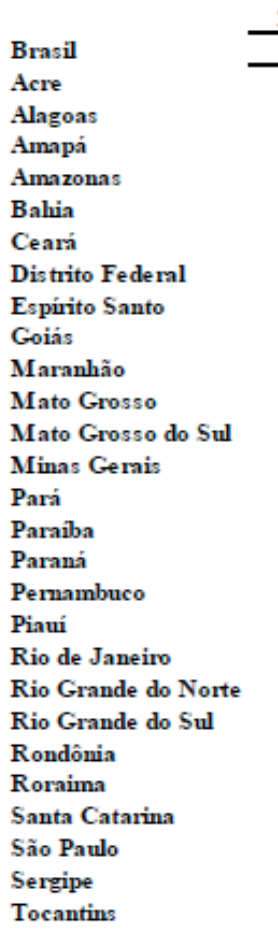

\begin{tabular}{|c|c|c|c|c|c|c|c|c|c|c|}
\hline 2006 & 2007 & 2008 & 2009 & 2010 & 2011 & 2012 & 2013 & 2014 & 2015 & 2016 \\
\hline 4,2 & 3,9 & 4,1 & 4,3 & 4,4 & 4,4 & 4,6 & 4,6 & 4,6 & 4,4 & 4,5 \\
\hline 4,5 & 5,2 & 3,7 & 4,4 & 5,2 & 4,8 & 4,2 & 8,2 & 5,1 & 4,7 & 5,7 \\
\hline 6,7 & 6,7 & 5,1 & 6,7 & 8,2 & 8,2 & 7,8 & 8,2 & 7,3 & 5,4 & 5,9 \\
\hline 4,2 & 3,7 & 4,0 & 3,6 & 4,7 & 5,4 & 4,6 & 5,1 & 5,3 & 4,7 & 4,4 \\
\hline 3,2 & 3,1 & 3,6 & 3,8 & 3,6 & 4,4 & 6,3 & 5,0 & 4,1 & 5,9 & 5,9 \\
\hline 3,3 & 3,4 & 4,3 & 4,6 & 5,8 & 5,8 & 5,7 & 5,5 & 4,9 & 4,9 & 5,7 \\
\hline 3,2 & 2,9 & 2,7 & 3,1 & 3,9 & 4,2 & 4,8 & 6,1 & 6,3 & 5,6 & 4,8 \\
\hline 3,9 & 4,3 & 4,8 & 5,6 & 4,8 & 5,6 & 5,4 & 5,2 & 4,1 & 3,8 & 4,1 \\
\hline 10,3 & 10,2 & 10,3 & 11,6 & 9,2 & 8,6 & 8,5 & 8,7 & 7,0 & 6,9 & 5,2 \\
\hline 4,9 & 4,7 & 5,3 & 5,3 & 5,7 & 8,1 & 7,6 & 8,4 & 8,7 & 7,5 & 7,1 \\
\hline 2,1 & 1,9 & 2,5 & 2,6 & 3,5 & 3,8 & 3,4 & 3,8 & 4,2 & 4,2 & 4,5 \\
\hline 4,9 & 6,6 & 5,9 & 6,3 & 5,3 & 5,7 & 6,4 & 5,7 & 7,0 & 7,3 & 6,4 \\
\hline 4,7 & 5,6 & 4,8 & 5,2 & 6,0 & 6,0 & 6,0 & 5,7 & 6,4 & 4,3 & 6,0 \\
\hline 3,9 & 4,0 & 3,7 & 3,9 & 3,9 & 4,4 & 4,4 & 4,0 & 3,8 & 3,9 & 3,6 \\
\hline 3,9 & 4,0 & 4,6 & 4,8 & 6,0 & 4,8 & 5,9 & 5,8 & 6,2 & 6,4 & 7,2 \\
\hline 3,3 & 3,6 & 4,5 & 5,0 & 6,0 & 6,9 & 6,7 & 6,1 & 5,7 & 5,3 & 5,2 \\
\hline 4,7 & 4,5 & 5,6 & 6,0 & 6,1 & 5,1 & 5,7 & 5,0 & 5,0 & 4,3 & 4,2 \\
\hline 6,9 & 6,4 & 6,5 & 6,5 & 5,3 & 5,5 & 4,5 & 5,3 & 4,9 & 4,8 & 5,8 \\
\hline 2,0 & 2,2 & 2,4 & 1,9 & 2,5 & 2,0 & 2,8 & 2,9 & 3,8 & 4,1 & 3,0 \\
\hline 6,1 & 5,0 & 4,4 & 4,1 & 4,0 & 4,2 & 4,3 & 4,4 & 5,3 & 4,4 & 5,0 \\
\hline 2,6 & 2,6 & 3,6 & 3,5 & 4,2 & 4,4 & 3,8 & 5,2 & 5,7 & 5,1 & 5,7 \\
\hline 2,9 & 3,5 & 3,9 & 4,0 & 4,0 & 3,5 & 4,3 & 3,6 & 4,3 & 4,9 & 5,4 \\
\hline 6,6 & 3,5 & 4,8 & 6,2 & 4,4 & 5,7 & 6,1 & 6,1 & 6,4 & 7,2 & 6,2 \\
\hline 6,4 & 8,9 & 7,1 & 10,6 & 4,8 & 4,3 & 7,1 & 14,8 & 9,5 & 11,4 & 10,0 \\
\hline 3,0 & 2,3 & 2,7 & 2,9 & 3,4 & 2,3 & 3,1 & 3,0 & 3,2 & 2,8 & 3,1 \\
\hline 3,7 & 2,8 & 3,1 & 3,1 & 3,1 & 2,6 & 2,8 & 2,7 & 2,7 & 2,4 & 2,2 \\
\hline 3,9 & 3,2 & 2,8 & 3,3 & 3,9 & 5,4 & 5,5 & 5,0 & 6,5 & 6,0 & 5,2 \\
\hline 3.3 & 4.1 & 3.1 & 4.5 & 4.8 & 6.8 & 6.6 & 5.3 & 4.7 & 6.4 & 6.0 \\
\hline
\end{tabular}

Fonte: Instituto de Pesquisa Econômica Aplicada (IPEA) e Fórum Brasileiro de Segurança Pública, Atlas da Violência (2018)

Assim como a figura 9, a figura 10 demonstra que, embora em alguns estados os números de homicídios contra mulheres sejam menores, ao analisar o todo a taxa de aumento dos crimes foi muito maior. 
O Atlas ainda fez uma análise da raça/cor da pele das vítimas. Vejamos os dados divulgados:

\section{Figura 11 - Evolução dos homicídios de mulheres negras em três UFs} com as maiores taxas em 2016 e no Brasil. Taxa por 100 mil mulheres

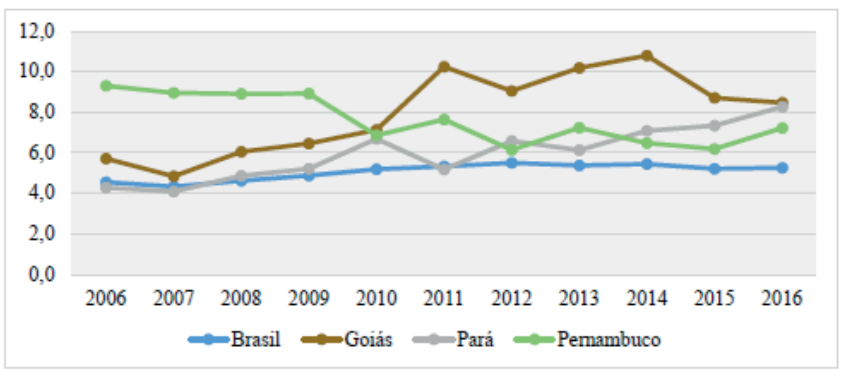

Fonte: Instituto de Pesquisa Econômica Aplicada (IPEA) e Fórum Brasileiro de Segurança Pública, Atlas da Violência (2018)

Observando a figura é possível notar que no estado de Goiás houve um aumento bruto no número de casos de feminicídio ao longo desses dez anos analisados.

\section{Figura 12 - Evolução dos homicídios de mulheres não negras em três UFs com as maiores taxas em 2016 e no Brasil. Taxa por 100 mil mulheres}

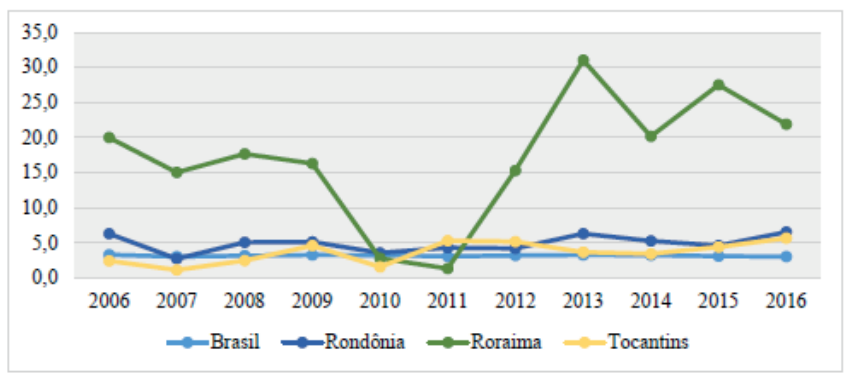

Fonte: Instituto de Pesquisa Econômica Aplicada (IPEA) e Fórum Brasileiro de Segurança Pública, Atlas da Violência (2018)

Nesta figura é possível analisar que no estado de Roraima, o número de mulheres assassinadas foi extremamente maior.

Em relação às figuras 11 e 12, cabe mencionar que os estados ali analisados são diferentes, ou seja, em determinadas regiões os números de mulheres negras assassinadas são maiores, e já em outros estados o número de mulheres brancas assassinadas é maior.

Em relação ao ano de 2016, o Atlas ainda concluiu que a taxa de homicídios entre as mulheres negras foi maior, representando $71 \%$ dos casos, enquanto entre as mulheres brancas houve uma queda de 8\%. Analisemos agora o ano de 2017.

Em 2019 O Instituto de Pesquisa Econômica Aplicada (IPEA) e o Fórum Brasileiro de Segurança Pública também publicaram o Atlas da Violência 2019. Nesse 
novo estudo foram analisados os índices de homicídio contra a mulher entre os anos de 2007 a 2017. Segundo o Atlas da Violência (2019, p. 35):

[...] houve um crescimento dos homicídios femininos no Brasil em 2017, com cerca de 13 assassinatos por dia. Ao todo, 4.936 mulheres foram mortas, o maior número registrado desde 2007. Os registros do Sistema de Informações sobre Mortalidade, do Ministério da Saúde, aqui analisados, trazem importantes subsídios para compreender melhor o fenômeno da violência letal contra a mulher, ao trazer dados sobre as características das vítimas e sobre alguns aspectos situacionais relacionados aos incidentes. Em particular, analisaremos nessa seção a evolução dos homicídios de mulheres nas unidades federativas e investigaremos se, de fato, houve crescimento dos casos de feminicídios nos últimos anos, que têm chamado a atenção da mídia, dos operadores e dos pesquisadores sobre segurança pública no país.

Observa-se que, segundo o Atlas, os feminicídios tiveram um grande aumento em 2017. Além disso, o Atlas (2019, p. 35) trouxe:

Entre 2007 e 2017 houve aumento de 20,7\% na taxa nacional de homicídios de mulheres, quando a mesma passou de 3,9 para 4,7 mulheres assassinadas por grupo de 100 mil mulheres. Nesse período, houve crescimento da taxa em 17 Unidades da Federação. Já no recorte de 2012 a 2017 , observamos aumento de $1,7 \%$ na taxa nacional e um aumento maior ainda de $5,4 \%$ no último ano, período em que se verificam taxas ascendentes em 17 UFs em relação a 2016. Considerando o período decenal, Rio Grande do Norte apresentou o maior crescimento, com variação de 214,4\% entre 2007 e 2017, seguido por Ceará (176,9\%) e Sergipe (107,0\%). Já no ano de 2017, o estado de Roraima respondeu pela maior taxa, com 10,6 mulheres vítimas de homicídio por grupo de $100 \mathrm{mil} \mathrm{mu-}$ lheres, índice mais de duas vezes superior à média nacional $(4,7)$. A lista das unidades federativas onde houve mais violência letal contra as mulheres é seguida por Acre, com taxa de 8,3 para cada 100 mil mulheres, Rio Grande do Norte, também com taxa de 8,3, Ceará, com taxa de 8,1, Goiás, com taxa de 7,6, Pará e Espírito Santo com taxas de 7,5.

Nota-se, que estados como Roraima e Goiás continuam entre os locais onde mais o crime ocorre. A seguir veremos as taxas de homicídios de mulheres no ano de 2017.

Analisando a figura 13 é possível notar que os números de homicídios contra mulheres estão altos em praticamente todas as regiões.

Ainda no que se refere aos casos de feminicídios ocorridos em 2017 o Atlas da Violência informou que (2019, p. 38):

Enquanto a taxa de homicídios de mulheres não negras teve crescimento de $4,5 \%$ entre 2007 e 2017, a taxa de homicídios de mulheres negras cresceu 29,9\%. Em números absolutos a diferença é ainda mais brutal, já que entre não negras o crescimento é de 1,7\% e entre mulheres negras 
Figura 13 - Taxa de homicídios por 100 mil mulheres nas UFs (2017)

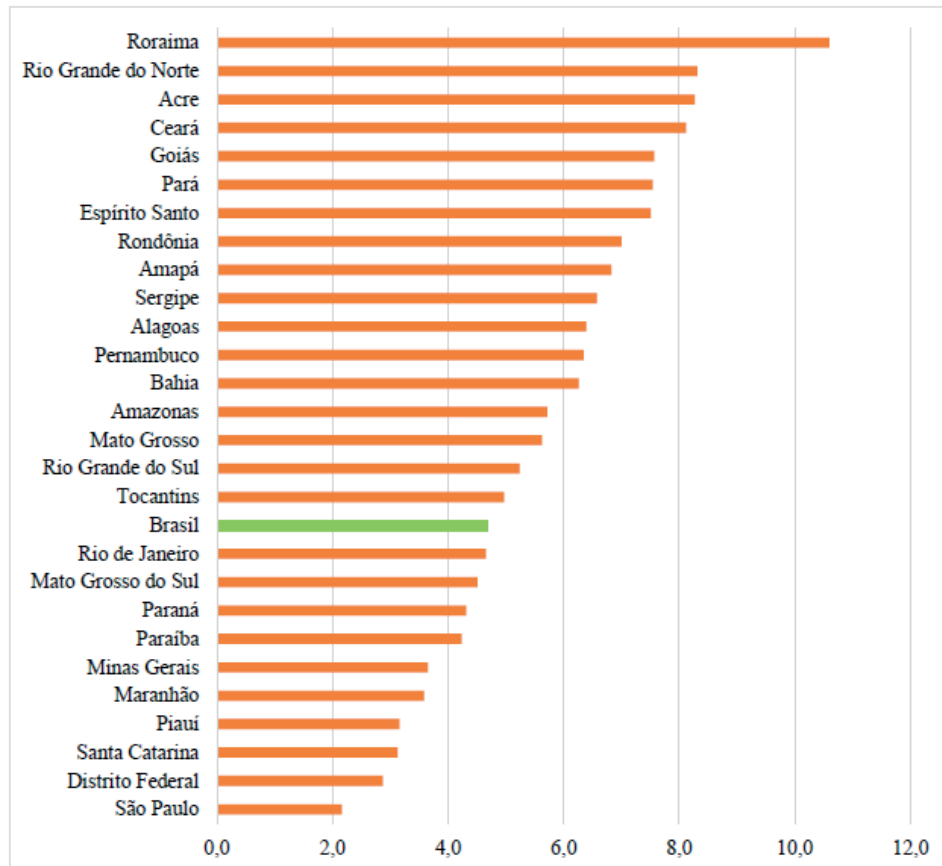

Fonte: Instituto de Pesquisa Econômica Aplicada (IPEA) e Fórum

Brasileiro de Segurança Pública, Atlas da Violência (2019)

de $60,5 \%$. Considerando apenas o último ano disponível, a taxa de homicídios de mulheres não negras foi de 3,2 a cada 100 mil mulheres não negras, ao passo que entre as mulheres negras a taxa foi de 5,6 para cada 100 mil mulheres neste grupo.

Veremos agora os dados referentes ao ano de 2018. Segundo o Anuário Brasileiro de Segurança Pública 2019, no ano de 2018 os índices de feminicídio nos estados do Brasil evidenciavam (Tabela 2).

Analisando a tabela 2 é possível notar que entre os dados de 2017 e 2018, embora os números não tenham variado muito, que em alguns estados houve queda do número de feminicídios e em outros houve aumento. Ademais, cumpre ressaltar os estados que tiveram os maiores índices de homicídios contra mulheres: Distrito Federal, Mato Grosso do Sul, Piauí e Rio Grande do Sul, que ultrapassaram a porcentagem de $50 \%$ de mortes. Os estados que tiveram menores índices de criminalidade contra as mulheres foram Amazonas e Ceará, não chegando nem a $10 \%$ de casos.

Analisaremos agora os dados que foram divulgados referentes ao ano de 2019. O Conselho Nacional do Ministério Público mantém um site onde divulga o número de feminicídios consumados e tentados ao longo do ano em alguns estados. Com base nisso iremos analisar os dados divulgados entre os dias 01/01/2019 a 10/11/2019. 
Tabela 2 - Homicídios de mulheres e feminicídios (2017/2018)

\begin{tabular}{|c|c|c|c|c|c|c|c|}
\hline \multicolumn{5}{|c|}{ Feminicídios } & \multirow{3}{*}{$\begin{array}{l}\text { Va- } \\
\text { riação } \\
(\%)\end{array}$} & \multicolumn{2}{|c|}{$\begin{array}{c}\text { Feminicídios em rela- } \\
\text { ção aos homicídios de } \\
\text { mulheres }\end{array}$} \\
\hline \multirow[t]{2}{*}{ Estados } & \multicolumn{2}{|c|}{$\begin{array}{c}\text { N. } .^{o} \text { absolu- } \\
\text { tos }\end{array}$} & \multicolumn{2}{|c|}{ Taxas } & & \multicolumn{2}{|c|}{ Em porcentagem $(\%)$} \\
\hline & 2017 & 2018 & 2017 & 2018 & & 2017 & 2018 \\
\hline Acre & 13 & 14 & 3,2 & 3,4 & 6,0 & 35,1 & 38,9 \\
\hline Alagoas & 34 & 21 & 2,0 & 1,2 & $-38,6$ & 45,9 & 33,3 \\
\hline Amapá & 2 & 5 & 0,5 & 1,2 & 145,2 & 7,1 & 29,4 \\
\hline Amazonas & 16 & 4 & 0,8 & 0,2 & $-75,4$ & 21,6 & 4,5 \\
\hline Bahia & 74 & 75 & 1,0 & 1,0 & 0,8 & 15,6 & 17,8 \\
\hline Ceará & 22 & 27 & 0,5 & 0,6 & 21,9 & 6,2 & 6,0 \\
\hline Distrito Federal & 18 & 28 & 1,1 & 1,7 & 52,3 & 43,9 & 62,2 \\
\hline Espirito Santo & 42 & 31 & 2,1 & 1,5 & $-27,0$ & 31,6 & 33,3 \\
\hline Goiás & 23 & 35 & 0,7 & 1,0 & 50,4 & 11,7 & 20,2 \\
\hline Maranhão & 51 & 44 & 1,4 & 1,2 & $-14,3$ & 45,1 & 44,4 \\
\hline Mato Grosso & - & 42 & - & 2,5 & $\ldots$ & 90,5 & 49,4 \\
\hline Mato Grosso do Sul & 29 & 36 & 2,1 & 2,6 & 22,7 & 49,2 & 57,1 \\
\hline Minas Gerais & 150 & 156 & 1,4 & 1,5 & 3,4 & 39,9 & 47,9 \\
\hline Pará & 49 & 63 & 1,2 & 1,5 & 27,1 & 17,2 & 20,4 \\
\hline Paraíba & 22 & 34 & 1,1 & 1,6 & 53,5 & 28,9 & 40,5 \\
\hline Paraná & 41 & 61 & 0,7 & 1,1 & 47,7 & 22,3 & 41,8 \\
\hline Pernambuco & 76 & 74 & 1,6 & 1,5 & $-3,3$ & 25,5 & 32,5 \\
\hline Piauí & 26 & 27 & 1,6 & 1,6 & 3,5 & 44,1 & 55,1 \\
\hline Rio de Janeiro & 68 & 71 & 0,8 & 0,8 & 3,9 & 17,8 & 20,4 \\
\hline Rio Grande do Norte & 23 & 28 & 1,3 & 1,6 & 20,6 & 15,4 & 27,7 \\
\hline Rio Grande do Sul & 83 & 117 & 1,4 & 2,0 & 40,5 & 27,2 & 57,1 \\
\hline Rondônia & - & 9 & 0,0 & 1,0 & 100,0 & - & 27,3 \\
\hline Roraima & 3 & 4 & 1,2 & 1,5 & 31,2 & 30,0 & 14,8 \\
\hline Santa Catarina & 52 & 42 & 1,5 & 1,2 & $-20,2$ & 46,8 & 44,2 \\
\hline São Paulo & 120 & 136 & 0,5 & 0,6 & 12,5 & 23,5 & 29,5 \\
\hline Sergipe & 6 & 16 & 0,5 & 1,4 & 163,9 & 9,4 & 43,2 \\
\hline Tocantins & 32 & 6 & 4,2 & 0,8 & $-81,5$ & 97,0 & 24,0 \\
\hline
\end{tabular}

Fonte: Anuário Brasileiro de Segurança Pública (2019)

(-) Fenômeno inexistente / (...) Informação não disponível. 
Tabela 3 - Número de feminicídios tentados e consumados em 15 estados brasileiros

\begin{tabular}{|l|r|r|}
\hline \multicolumn{2}{|c|}{ Feminicídio } \\
UF & Consumado & \multicolumn{2}{|c|}{ Tentado } \\
\hline Distrito Federal & 26 & 139 \\
\hline Goiás & 0 & 2 \\
\hline Mato Grosso & 2 & 22 \\
\hline Mato Grosso do Sul & 0 & 18 \\
\hline Bahia & 22 & 18 \\
\hline Ceará & 3 & 34 \\
\hline Maranhão & 1 & 3 \\
\hline Rio Grande do Norte & 2 & 4 \\
\hline Sergipe & 0 & 8 \\
\hline Pará & 7 & 19 \\
\hline Rondônia & 13 & 58 \\
\hline Roraima & 0 & 20 \\
\hline Espírito Santo & 8 & 29 \\
\hline Rio de Janeiro & 0 & 81 \\
\hline São Paulo & 14 & 154 \\
\hline Total & 98 & 609 \\
\hline
\end{tabular}

Conselho Nacional do Ministério Público (2019)

Analisando a tabela 3 é possível notar que o Distrito Federal e os estados da Bahia, Rondônia e São Paulo foram os lugares onde o crime de feminicídio mais fez vítimas, ultrapassando a marca de 10 mulheres mortas até o dia 10/11/2019. E em que pese os números estarem relativamente baixos em comparação aos outros anos analisados, o número de feminicídios tentados estão altíssimos em praticamente todos os 15 estados analisados. Ou seja, muitas mortes não foram consumadas porque algo impediu essa violência fatal contra a mulher.

\section{CONSIDERAÇÕES FINAIS}

Com base no que foi estudado neste artigo, podemos fazer algumas considerações a respeito do que foi analisado ao longo deste trabalho.

A entrada em vigor da Lei 13.104/2015, que tipificou a qualificadora do feminicídio no Código Penal Brasileiro, foi outro marco de estrema relevância para o Brasil, pois ajuda a mapear a violência de gênero de forma mais eficaz, punindo os agressores de maneiras mais severas a fim de que tais crimes cada vez mais diminuam.

Ademais, muito embora o número de vítimas fatais ainda seja crescente, e a violência contra a mulher algo muito presente em nossa sociedade, temos que concordar que a legitimação de leis a favor da mulher surgem como forma de mudança social, criando parâmetros para que não só as vítimas, mas a pessoas que 
convivem com ela, denunciem os agressores e acabem com esse ciclo de agressões que passa de geração em geração.

Entretanto, é nítido que a violência de gênero é um problema longe de ser solucionado no Brasil, pois os padrões patriarcais estão atingindo todos os tipos de pessoas e, se a sociedade não mudar e não houver incentivo dos órgãos governamentais para que as mulheres denunciem qualquer tipo de agressão, desde um tapa ou um xingamento que abale seu equilíbrio psicológico, todos os anos o número de feminicídios tenderá a aumentar gradativamente, afinal as pesquisas quantitativas, estudadas ao longo desse trabalho, demonstram que os números vêm crescendo ao longo dos anos.

Conclui-se, pois, que a violência contra a mulher está longe de acabar e, dessa forma, embora tenhamos muitas leis de proteção à mulher em razão de gênero, entendemos imperioso que essas leis sejam mais divulgadas nas mídias sociais e, principalmente, que haja mais incentivo para que as mulheres denunciem seus agressores em curto espaço de tempo.

\section{REFERENNCIAS}

ANUÁRIO BRASILEIRO DE SEGURANÇA PÚBLICA, 2019. Disponível em: http://www. forumseguranca.org.br/wp-content/uploads/2019/10/Anuario-2019-FINAL_21.10.19. pdf. Acesso em 02 nov. 2019.

BRASIL, Decreto no 29.981/1989 Disponível em: https://www.al.sp.gov.br/repositorio/ legislacao/decreto/1989/decreto-29981-01.06.1989.html . Acesso em 13 ago. 2020

BRASIL, Lei 11.340/2006 Disponível em: http://www.planalto.gov.br/ccivil_03/_ Ato2004-2006/2006/Lei/L11340.htm . Acesso em: 11 set. 2019.

BRASIL, Lei 13.104/15 Disponível em: www.planalto.gov.br/CCIVIL_03/_Ato20152018/2015/Lei/L13104.htm. Acesso em: 11 set. 2019.

BRASIL, Senado Federal. Comissão Parlamentar Mista de Inquérito. Relatório Final. Brasília, 2013. Disponível em: https://www2.senado.leg.br/bdsf/item/id/496481 . Acesso em 27 out. 2019.

BRASIL. Constituição Federal de 1988. Promulgada em 5 de outubro de 1988.

BRASIL. Superior Tribunal de Justiça. Recurso Ordinário n ${ }^{0}$ 201602455869. Quarta turma. Relator: ministro Luís Felipe Salomão. Brasília, DF, 09 de maio de 2017. Dje. Brasília, 09 maio 2017. Disponível em: https://scon.stj.jus.br/SCON/jurisprudencia/toc.jsp . Acesso em: 08 set. 2019.

BRASIL. Tribunal de Justiça do Estado do Rio Grande do Sul. Embargos Infringentes e de Nulidade, No 70077233740. Primeiro Grupo de Câmaras Criminais. Relator: Sylvio Baptista Neto, RS, 04 de maio de 2018. Dje. Rio Grande do Sul, 04 maio 2017. Disponível em: http://www.tjrs.jus.br/site/busca-solr/index.html?aba=jurisprudencia . Acesso em: 14 nov. 2019. 
CONSELHO NACIONAL DO MINISTÉRIO PÚBLICO. Cadastro de Feminicídio. 2019. Disponível em: https://www.cnmp.mp.br/portal/relatoriosbi/cadastro-de-feminicidio . Acesso em: 09 nov. 2019.

CUNHA, Rogério Sanches. Código Penal para Concursos, 10ª ed., São Paulo: Juspodivm, 2017.

DIÁRIOPB, Brasil está em $5^{\circ}$ lugar em ranking de feminicídios, no mundo aposta OMS. Disponível em: https://diariopb.com.br/brasil-esta-em-5o-lugar-em-ranking-de-feminicidios-no-mundo-aponta-oms/ . Acesso em: 24 abril. 2019.

FÓRUM BRASILEIRO DE SEGURANÇA PÚBLICA E INSTITUTO DATAFOLHA. Visível e Invisível: A Vitimização de Mulheres no Brasil. 2. ed. 2019. 50 p. Disponível em: http:/ / www.forumseguranca.org.br/wp-content/uploads/2019/02/relatorio-pesquisa-2019-v6. pdf. Acesso em: 21 set. 2019.

FRANÇA, Genival Veloso. Fundamentos de medicina legal. Rio de Janeiro: Editora Guanabara Koogan, 2005, p. 142.

GOMES, Luiz Flávio; BIANCHINI, Alice. Feminicídio: entenda as questões controvertidas da Lei 13.104/2015. Disponível em: https://professorlfg.jusbrasil.com.br/artigos/173139525/feminicidio-entenda-as-questoes-controvertidas-da-lei-13104-2015 . Acesso em: 14 nov. 2019.

INSTITUTO DE PESQUISA ECONÔMICA APLICADA (IPEA) E FÓRUM BRASILEIRO DE SEGURANÇA PÚBLICA. Atlas da Violência. 2018. Disponível em:http://www.forumseguranca.org.br/wpcontent/uploads/2018/06/FBSP_Atlas_da_Violencia_2018_Relatorio.pdf . Acesso em 06/11/2019.

INSTITUTO DE PESQUISA ECONÔMICA APLICADA (IPEA) E FÓRUM BRASILEIRO DE SEGURANÇA PÚBLICA. Atlas da Violência. 2019. Disponível em: http:/ / www.ipea. gov.br/portal/images/stories/PDFs/relatorio_institucional/190605_Atlas_da_violencia_2019.pdf. Acesso em 06/11/2019.

INSTITUTO DE SEGURANÇA PÚBLICA DO RIO DE JANEIRO. Dossiê Mulher, 2017, 2018. Disponível em: https://public.tableau.com/profile/instituto.de.seguran.a.p.blica. isp\#!/vizhome/DossiMulher_0/Resumo.

INSTITUTO DE SEGURANÇA PÚBLICA DO RIO DE JANEIRO. Dossiê Mulher 2018. Disponível em: http://arquivos.proderj.rj.gov.br/isp_imagens/uploads/DossieMulher2018.pdf . Acesso em 04/11/2019.

INSTITUTO DE SEGURANÇA PÚBLICA. Dossiê Mulher 2019. Rio de Janeiro, 2019. Disponível em: http://arquivos.proderj.rj.gov.br/isp_imagens/uploads/DossieMulher2019. pdf. Acesso em: 12 out. 2019.

MELLO, Adriana Ramos de. Feminicídio: uma análise sociojurídica da violência contra a mulher no brasil. Rio de Janeiro: Gz, 2019.

MIGALHAS. Senado aprova PEC que torna crime de feminicídio imprescritível. 2019. Disponível em: https:/ / www.migalhas.com.br/Quentes/17,MI314687,91041-Senado+apro$\mathrm{va}+\mathrm{PEC}+\mathrm{que}+$ torna+crime+de+feminicidio+imprescritivel . Acesso em: 04 nov. 2019. 
NUCCI, Guilherme de Souza, Curso de Direito Penal. Parte Especial. Volume 2. Rio de Janeiro: Forense, 2017.

ORTEGA, Flávia Teixeira. Feminicídio:(art. 121, § 2 , VI, do CP). 2016. Disponível em: https://draflaviaortega.jusbrasil.com.br/artigos/337322133/feminicidio-art-121-2-vi-do-cp . Acesso em: 08 nov. 2019.

PIRES, Amom Albernaz. A natureza objetiva da qualificadora do feminicídio e sua quesitação no Tribunal do Júri. Disponível em: https://amomalbernaz.jusbrasil.com.br/artigos/172762972/a-natureza-objetiva-da-qualificadora-do-feminicidio-e-sua-quesitacao-no-tribunal-do-juri . Acesso em: 04 nov. 2019.

PUREZA, Diego Luiz Victório. O transexual como vítima do feminicídio. Disponível em: https://jus.com.br/artigos/42981/o-transexual-como-vitima-do-feminicidio . Acesso em: 11 out. 2019.

SENADO FEDERAL. Panorama da violência contra as mulheres no Brasil indicadores nacionais e estaduais. 2018. Disponível em: http://www.senado.gov.br/institucional/ datasenado/omv/indicadores/relatorios/BR-2018.pdf . Acesso em: 06 nov. 2019. 